\title{
Electromagnetic Radiation from Mobile Phone near Ear-skull Region
}

\author{
Dayang Azra Awang Mat \\ Department of Electronics Engineering \\ Universiti Malaysia Sarawak \\ 94300 Kota Samarahan, Sarawak. \\ amdazra@feng.unimas.my
}

\author{
Franky Kho, Annie Joseph, Kuryati Kipli, Shafrida \\ Sahrani, Kasumawati Lias \& Ade Syaheda Wani \\ Marzuki \\ Department of Electronics Engineering \\ Universiti Malaysia Sarawak \\ 94300 Kota Samarahan, Sarawak \\ jannie@feng.unimas.my, kkuryati@feng.unimas.my, \\ sshafrida@feng.unimas.my
}

\begin{abstract}
Mobile phones produce radio frequency signal that is transferred as Electromagnetic radiation (EMR). EMR has the ability to penetrate through semi solid substances especially human body's tissues and caused dielectric heating. This effect can be classified as thermal and non thermal radiation. The skin near ear skull region is very thin compare to other part of human body. When using mobile phone for a longer period of time, this area absorbs EMR easily that can affects human immune systems. This effect resulted the increased of temperature near the ear skull region. Experimental study was conducted by using a volunteer to examine the effect of EMR produced by two different mobile phones with serving frequency of $900 \mathrm{MHz}$ and $1800 \mathrm{MHz}$. This study was done in a laboratory for average of 45 minutes of talking time. Data is collected every 5 minutes using thermal imaging camera and thermal couples' probes. It is shown that temperature near the ear-skull region increased rapidly at the average of $2-4^{\circ} \mathrm{C}$ differences compare to before the used of mobile phone. When using adds in tools, the temperature rose more gradually and minimally. It is proven that the EMR would not cause any adverse effect towards human health such as cancer or tumor.
\end{abstract}

Keywords- electromagnetic radiation, mobile phone, Bluetooth headset, earphone

\section{INTRODUCTION}

The number of mobile phone users has increased exponentially recently and mobile phone has become an important device in human daily life. Estimates suggested there are around 1.6 billion mobile phone users throughout the world and these numbers are increasing [1]. Mobile phone is a sophisticated two-way radio that use radio frequency (RF) signals to transmit and receive voice and data [2]. Mobile phone communicates with a network of low powered radio transceivers called base stations. The coverage area of the communication services is called cell. In a cell, there are seven clusters where each of them has different frequencies. Cells are interlinked next to each other to create the cellular network [3].

GSM (Global System for Mobile Communication) is a cellular network used by mobile phone where mobile phone is connected to the cellular network by searching of cells in the immediate surrounding area [4]. GSM networks operate in four different frequency ranges which are $900 \mathrm{MHz}$ band, $1800 \mathrm{MHz}$ band, $850 \mathrm{MHz}$ band and $1900 \mathrm{MHz}$ band. GSM 900 and GSM 1800 standard are the most commonly used standard. $850 \mathrm{MHz}$ band and $1900 \mathrm{MHz}$ band were introduced because the $900 \mathrm{MHz}$ and $1800 \mathrm{MHz}$ frequency bands were already allocated [4]. GSM 1800 standard provide more bandwidth and less power requirements than GSM $900 \mathrm{MHz}$ [5]. The transmission power in the mobile phone is limited to a maximum of 2 watts in GSM 850 and GSM 900 while maximum power of 1 watt in GSM 1800 and GSM 1900 [4]. The specification of GSM 900 and GSM 1800 are shown in Table 1.

TABLE I. SPECIFICATIONS OF GSM 900 AND GSM 1800 [4][5]

\begin{tabular}{|c|c|c|}
\hline & GSM 900 & GSM 1800 \\
\hline Downlink Frequencies & $935-960 \mathrm{MHz}$ & $\begin{array}{c}1710-1785 \\
\mathrm{MHz}\end{array}$ \\
\hline Uplink Frequencies & $890-915 \mathrm{MHz}$ & $\begin{array}{c}1805-1880 \\
\mathrm{MHz}\end{array}$ \\
\hline Channel Spacing & $200 \mathrm{kHz}$ & $200 \mathrm{kHz}$ \\
\hline Modulation & GMSK & GMSK \\
\hline $\begin{array}{c}\text { Maximimum Base Station Transmit } \\
\text { Power }\end{array}$ & $2 \mathrm{~W}$ & $1 \mathrm{~W}$ \\
\hline Maximum Distance & $320 \mathrm{~W}$ & $20 \mathrm{~W}$ \\
\hline Speech Encoding & LPC $(13 \mathrm{kbit})$ & $8 \mathrm{~km}$ \\
\hline Bit-Rate & $270 \mathrm{kbps}$ & $270 \mathrm{kbps}$ \\
\hline
\end{tabular}

Radio frequency has the ability to penetrate through semisolid substances like meat, and living tissue to a distance proportional to its power density [6]. It also can cause dielectric heating effect or thermal effect [1][7]. Thermal effects are the temperature rise in the body cause of energy absorption from oscillating electric fields or electromagnetic radiation [8]. Thermal radiation also induced when mobile phone is used to make a call or receive a call for a long period of time. Thermal radiation is generated when heat from the movement of charged particles within atoms of the mobile 